\title{
Three years with a knife stuck in the brain
}

\author{
Luiz Coutinho Dias Filho ${ }^{1,2}$, Alex Caetano de Barros ${ }^{1}$, Marina Félix da Mota ${ }^{3}$ \\ Faculty of Medicine, Pernambuco Federal University (UFPE), Recife, PE, Brazil. Faculty of Medicine, Pernambuco University \\ (UPE), Recife, PE, Brazil.
}

\section{ABSTRACT}

Cranial stabbing injuries penetrating the brain are not commonly encountered. The cases in which the knife is retained constitute a challenge to the neurosurgeon. When a long-term permanence occurs, the reaction to the presence of the foreign body causes adherence to the nervous tissue and a higher risk is expected from the removal. The procedure should be performed with meticulous dissection and minimal oscillation of the blade thus avoiding damage to the adjacent structures. We report a case of a man who remained three years with a knife blade deeply lodged in the brain. After obtaining informed consent, the blade was removed; there were no postoperative complications. To our knowledge, this is the first case in which, after years of permanence, a knife blade was removed from the brain through a craniotomy.

\section{KEYWORDS}

Craniotomy, head injuries penetrating, puncture wounds, stab.

\section{RESUMO}

Três anos com uma faca cravada no encéfalo

Lesões cranianas por arma branca com penetração do encéfalo não são comuns. Os casos em que a faca encontra-se retida constituem um desafio para o neurocirurgião. Quando ocorre uma longa permanência, a reação à presença do corpo estranho causa aderência ao tecido nervoso e um maior risco é previsto para a remoção. O procedimento deve ser realizado com dissecção meticulosa e mínima oscilação da lâmina, evitando, assim, lesão das estruturas adjacentes. Apresentamos o caso de um indivíduo que permaneceu três anos com a lâmina de uma faca alojada profundamente no encéfalo. Após obtermos consentimento informado, a lâmina foi removida; não houve complicações pós-operatórias. Até onde sabemos, este é o primeiro caso em que, após anos de permanência, a lâmina de uma faca foi removida do encéfalo por meio de uma craniotomia.

\section{PALAVRAS-CHAVE}

Craniotomia, traumatismos cranianos penetrantes, ferimentos perfurantes, facada.

1 Neurosurgeon, Department of Neurology and Neurosurgery, Faculty of Medicine, Pernambuco Federal University (UFPE), Recife, PE, Brazil.

2 Professor of Anatomy, Department of Morphology, Faculty of Medicine, Pernambuco University (UPE), Recife, PE, Brazil.

3 Medical Student, Department of Morphology, Faculty of Medicine, UPE, Recife, PE, Brazil. 


\section{Introduction}

Brain injuries by knife are relatively uncommon. The low speed of the object to cross the nervous tissue explains why the lesion typically is restricted to the path of the blade and, therefore, when there is no injury of large vessels or involvement of vital areas such as the brainstem, the patient often gets conscious and with good chances of recovery. ${ }^{1-3}$ It is assumed that such patients have a higher incidence of complications when the blade is retained inside the skull, as there may be recurrence of bleeding in areas that were tamponade or adding of nervous injuries caused by movements of the blade during removal. ${ }^{4}$ When the blade remains for a long period, it is expected that the risk increases as the erosion makes the metal surface less smooth and there is possibility of adherence to adjacent tissue. We describe the case of a man who remained three years with the blade of a knife stuck in the brain. To our knowledge, this is the first case in which, after years of permanence, a knife blade is removed from the cerebrum through a craniotomy; there is a report describing the remotion of a blade fragment which was retained in the head for three years, however, in this case, the foreign body was retained into the bone, the brain was not stricken. ${ }^{5}$ As the metal blade of a knife was not manufactured with the properties of an object destined to remain inserted in biological tissues, it is expected that it will lead to a reactive process that results in adhesion; we found that this actually happens and describe the strategy used to deal with such a problem.

\section{Case report}

A 29-year-old man went to the Clinical Hospital of the Federal University of Pernambuco with a complaint of persistent headache that arose after he was stabbed in his head during an altercation. The incident occurred three years before and shortly after the aggression, he was taken to the emergency room of another hospital, where he was admitted unconscious. According to him, the doctors who treated him decided to break the knife close to the skull, and sutured the wound of the scalp later on; and they did so because they assumed that the extraction of the blade would have fatal consequences. There was post-traumatic amnesia and he showed a pattern somewhat aloof and sometimes aggressive behavior, which, however, did not last long and his life not only returned to normal due to the hassle of a persistent headache, which did not cease with the usual painkillers. At Clinical Hospital the patient underwent thorough neurological and psychological examina- tions, and no abnormalities had been detected. Plain skull radiographs revealed a knife blade broken off just above the skull, which penetrated the left frontal region, pointing down, back and inside, with its tip near the right posterior clinoid process (Figure 1). CT scanning confirmed the finding of radiographs. Arteriography showed no damage of brain vessels. The patient was warned about the risks associated with surgical removal of the blade, and stated that he would rather die than continue living with a knife in the brain.

A

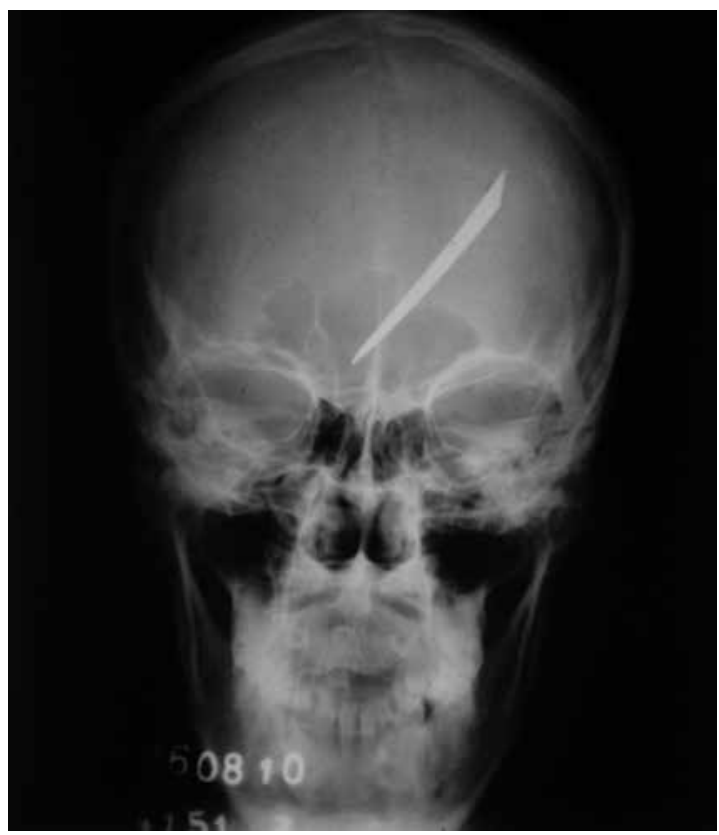

B

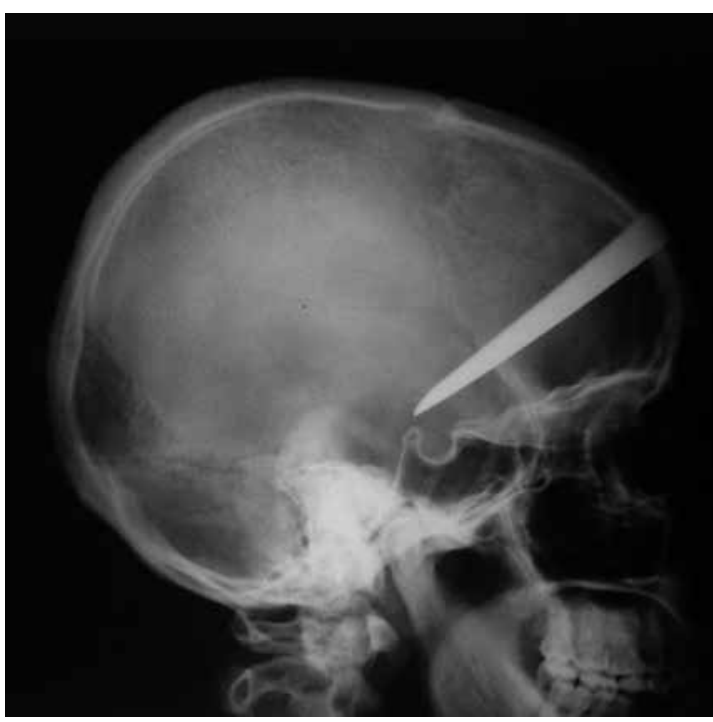

Figure 1 - Skull radiographs.

As the knife was divided close to the skull, two pins of a Caspar cervical distractor system were screwed in the area of bone surrounding the blade, in order to provide support for manual sustenance of the bone flap 
(Figure 2). Lying about $2 \mathrm{~cm}$ of the knife, a trepanation was made and craniotomy was initiated from this point. Previously, four pairs of holes were made for introducing the screws which would be used to fix four small metallic plates. The plates would be successively applied to hold the bone flap to the skull as the craniotomy took place, reducing the risk of oscillations of the blade during the procedure (Figure 2). After completion of craniotomy, the metal plates were released from the skull, the bone flap was held immovable, using the Caspar retractor

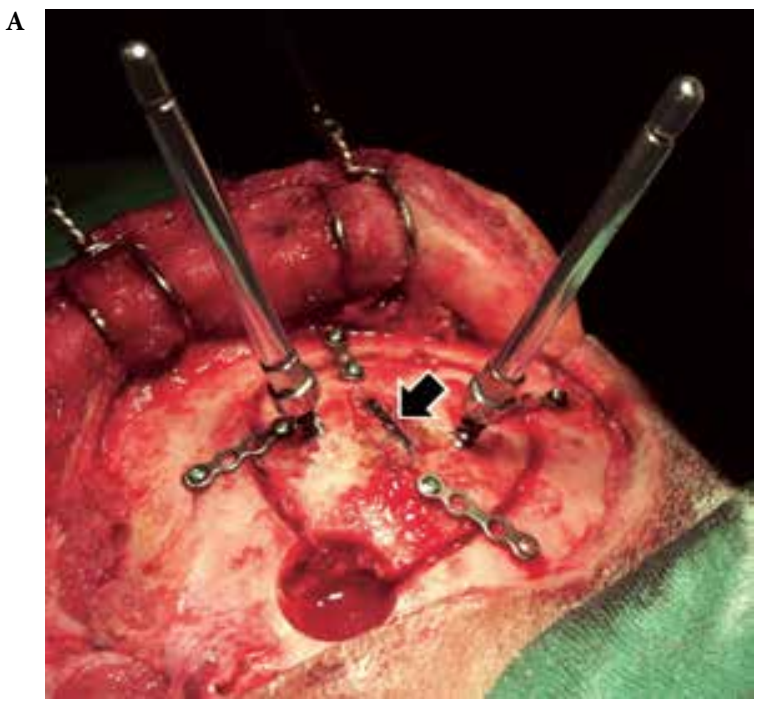

B

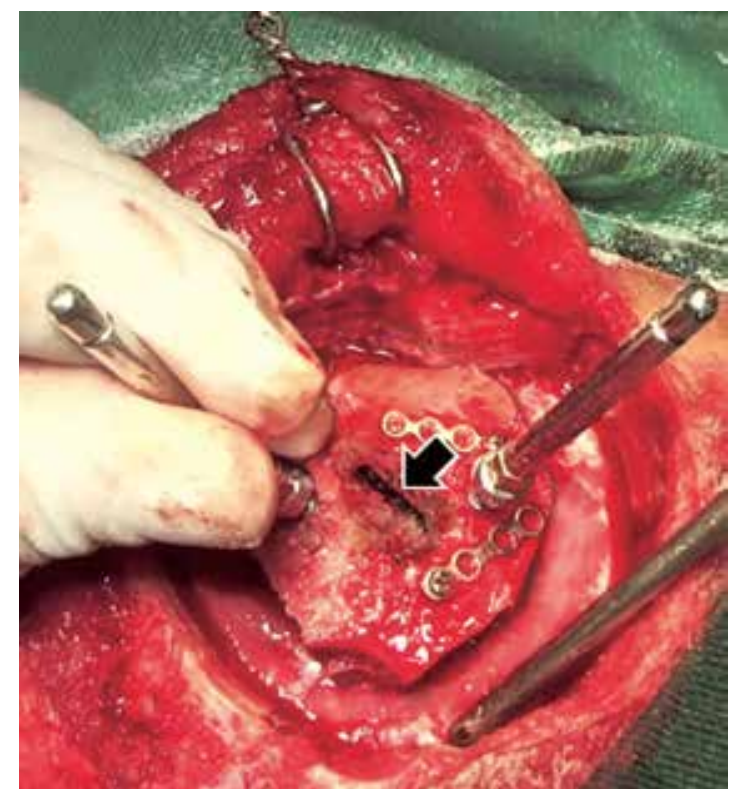

Figure 2 - (A) After reflecting the scalp, the knife blade (arrow) was found firmly lodged in the frontal bone. As craniotomy was performed, the bone flap was secured to the skull by means of metal plates and screws. The Caspar retractor pins were used to facilitate the fixing of the bone flap with the intent to prevent unnecessary movement of the blade. (B) While the assistant held the flap using a pin at times on one side at times on the other one as a support, the metal plates were released from the skull and a craniectomy was performed around the bone flap (the tip of the aspirator was on the dura). pins as support, and a craniotome was used to remove a strip of skull bone; so a gap of approximately $1,5 \mathrm{~cm}$ was created around the bone flap. Then, the dura was opened and the brain was gently depressed until the blade be achieved. Gentle traction along the axis of the knife allowed to assume that the object was attached to the cerebrum; maintaining minimum traction, the metal was separated from nervous tissue by gentle removal and dissection, taking care to avoid oscillation or rotation of the blade. Finally, the blade was removed (Figure 3). During the procedure no important vessel was injured. A graft was used to close the dura and then

A

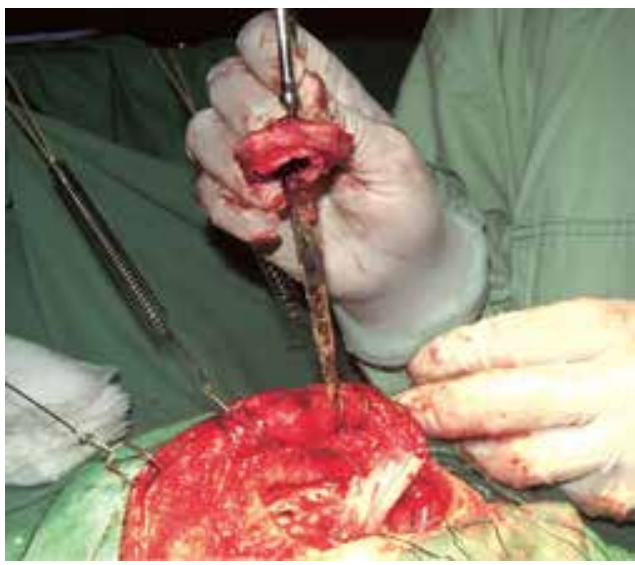

B

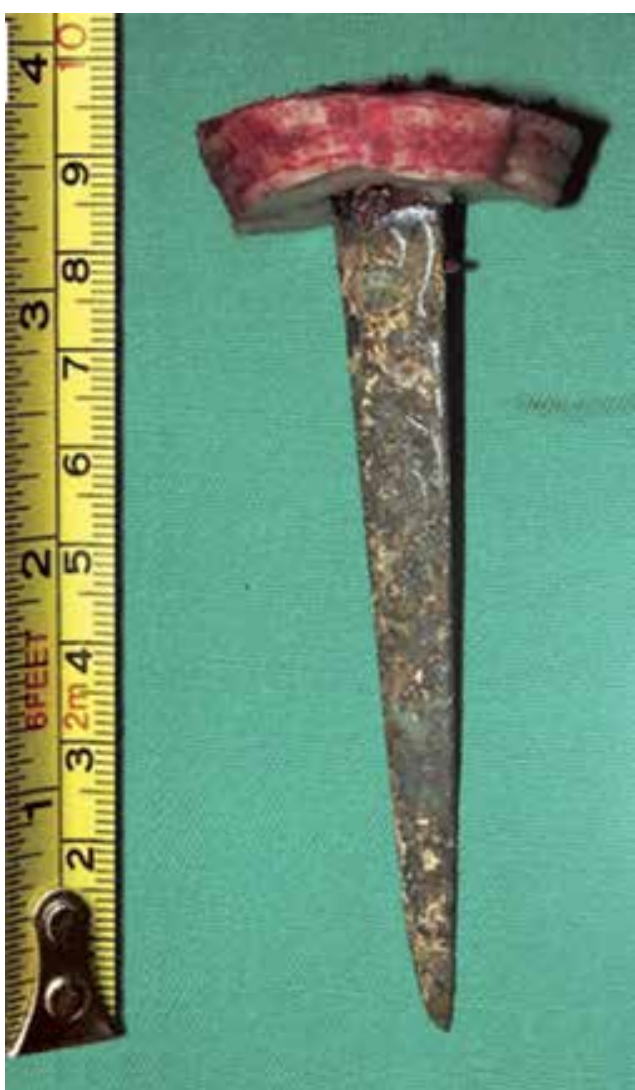

Figure 3 - (A) Time when the knife was finally removed. (B) The blade was $10 \mathrm{~cm}$ long. 
a cranioplasty was performed. The blade was about $10 \mathrm{~cm}$ in length, with a maximum width of $1,5 \mathrm{~cm}$; due to the effect of corrosion, its surface was rough (Figure 3 ).

Recovery was fast and uneventful. The neurological and psychological examinations performed shortly before hospital discharge revealed no abnormalities.

\section{Discussion}

In most penetrating skull injuries by knife, the weapon is drawn by the offender; in these cases, treatment consists mainly of wound debridement, hemostasis, dural repair and administration of antibiotics. ${ }^{1,6}$ When the blade remains retained, it is necessary to remove it, and to do so, the approach must be carefully planned, due to the risk of recurrent bleeding in areas that were tamponade and additional injuries due to mobilization of the blade. ${ }^{1,7}$ When a long-term permanence in nervous tissue occurs, it is expected that the reaction to the presence of the foreign body causes adhesion, as occurred in the case presented; it makes removal more difficult, requiring meticulous dissection to separate the blade from the surrounding tissue. Plain radiograph allows to assess the dimensions and location of the foreign body; computed tomographic scan, besides providing additional information regarding the size and path of the blade, allows the diagnosis of hematoma or abscess. It is also important to perform an arteriography to check for large vessels nearby and to discard the existence of aneurysms or traumatic arteriovenous fistulas. ${ }^{1,7}$

As usual, the craniotomy was performed with the object at its center, being small so that the flap does not obstruct the line of sight of the surgeon; to facilitate access to the affected area, a strip of bone was extracted from the skull, broadening the exposed region of the cerebrum. Blade movement can occur during craniotomy, especially at the end of procedure; ${ }^{8}$ fixation with metal plates minimized this risk. During removal, gentle traction is useful; however, it should be strictly held along the axis of blade. ${ }^{1}$ To prevent unwanted movements, it was crucial to have good support for the surgeon assistant firmly hold the bone flap assembly with the blade, this was obtained by means of the Caspar retractor pins. As there was no evidence of infection, it was decided to perform cranioplasty immediately. Antibiotic and anticonvulsant were administered prophylactically.

Cases of penetrating wounds of the head by objects with a small impact area and low kinetic energy are described as "Jael's syndrome", in allusion to the biblical story of Jael, who killed Sisera, the defeated
Canaanite Army Chief, nailing him a stake in the skull while he was asleep (Judges 4: 21); ${ }^{9-11}$ stories like this lead to disastrous consequences prediction when a weapon penetrates deep in the brain. Thus, see that an individual presents no objective neurological deficit after removal from a blade of four inches, which was stuck in his cerebrum for years, causes perplexity and it is understood that such a case has had great repercussion in the press (a photograph of the patient after surgery, contemplating his skull radiograph, circulates the Internet and can be seen on the links http://www. nbcnews.com/id/39369444/\#.UWGHbKL7KSp and http://www.cbsnews.com/8301-504763_162-2001766510391704.html).

\section{Conclusion}

We believe that several factors contributed to this favorable outcome: (1) Bone penetration in a thick area with loss of most of the energy to pass through the skull; (2) Small blade width; (3) Commitment of a "noneloquent" brain region; (4) Absence of major vascular injury; (5) Absence of infection; (6) Careful release of adhesions; (7) Maximum care to avoid oscillatory movements or twisting of the blade during its withdrawal.

\section{Competing interests}

The authors declare no conflict of interest.

\section{References}

1. Herring CJ, Lumsden AB, Tindall SC. Transcranial stab wounds: a report of three cases and suggestions for management. Neurosurgery. 1988;23(5):658-62.

2. Mitra K, Richards PJ, Oakley PA. Self-inflicted transcranial stab wound of the pons. Injury. 2002;33(4):374-6.

3. Bauer M, Patzelt D. Intracranial stab injuries: case report and case study. Forensic Sci Int. 2002;129(2):122-7.

4. Taylor AG, Peter JC. Patients with retained transcranial knife blades: a high-risk group. J Neurosurg. 1997;87(4):512-5.

5. Patel PM, Blackburn TP, Tait MJ, Strong AJ. Cranial blade: retained for three years. Br J Neurosurg. 2004;18(1):74-5.

6. Khalil N, Elwany MN, Miller JD. Transcranial stab wounds: morbidity and medicolegal awareness. Surg Neurol. 1991;35(4):294-9.

7. Iwakura M, Kawaguchi T, Hosoda K, Shibata Y, Komatsu $H$, Yanagisawa $A$, et al. Knife blade penetrating stab wound to the brain - case report. Neurol Med Chir (Tokyo). 2005;45(3):172-5. 
8. Dempsey LC, Winestock DP, Hoff JT. Stab wounds of the brain. West J Med. 1977;126(1):1-4.

9. Caldicott DG, Pearce A, Price R, Croser D, Brophy B. Not just another "head lac"...low-velocity, penetrating intracranial injuries: a case report and review of the literature. Injury. 2004;35(10):1044-54.

10. Feinsod M. Three head injuries: the Biblical account of the deaths of Sisera, Abimelech and Goliath. J Hist Neurosci. 1997;6(3):320-4.
11. McKechnie J. A severe craniofacial impalement injury (Jael's syndrome). Br J Oral Maxillofac Surg. 1986;24(4):258-64.

Correspondence address

Dr. Luiz Coutinho Dias Filho

Estrada de Aldeia, $\mathrm{km} \mathrm{14}$,

Condomínio Casa Grande de Aldeia,

Casa 87, Aldeia, Camaragibe

54786-001 - Recife, PE, Brazil

Telephone: (55 81) 3459-4171

E-mail: Idiasfilho60@gmail.com 